\title{
Relevance of Declining Agriculture in Economic Development of South Asian Countries: An Empirical Analysis
}

\author{
Saghir Ahmad Ansari, Waseem Khan \\ Department of Agricultural Economics and Business Management, Aligarh Muslim University, \\ Aligarh - 202002, India
}

\begin{abstract}
Role of agriculture has been a matter of debate among development economist. Agriculture has been a major contributor in national income and employment in South Asian economies but its share in the national GDP has been declining over time. This study examines the relevance of declining agriculture due to structural transformation in economic growth of four South Asian countries namely India, Pakistan, Sri Lanka and Bangladesh. To analyze the long-run relationship between agriculture and economic growth, an empirical model based on Augmented Neoclassical Solow-Swan model is developed. Johansen and Juselius (1990) maximum likelihood technique based on VAR model and Granger causality test has been employed to analyze long run and short run causal relations between agriculture and economic growth respectively. Results show that in all four South Asian countries, agriculture has long-run association with economic growth and it is an important driver of economic growth. Short-run analysis indicates that agriculture stimulates economic growth in all South Asian countries except Bangladesh. Neglect of agriculture and excessive focus on industrialization may retard growth both in short and long run.
\end{abstract}

\section{Keywords}

Agriculture, economic growth, South Asia.

Ansari, S. A. and Khan, W. (2018) "Relevance of Declining Agriculture in Economic Development of South Asian Countries: An Empirical Analysis", AGRIS on-line Papers in Economics and Informatics, Vol. 10, No. 2, pp. 3-14. ISSN 1804-1930. DOI 10.7160/aol.2018.100201.

\section{Introduction}

Economic literature and empirical studies provide us with sufficient evidence that agricultural development is a basic pre-condition for economic development of a country. Rostow (1959) argued that "revolutionary changes in agricultural productivity are an essential condition for successful take-off." The agricultural sector has the potentials to facilitate industrial and service sector expansion to create the takeoff environment. England, for example, relied heavily on its domestic agriculture in the early phase of its industrial revolution. In most of the western European countries such as France, Belgium, Germany, and Sweden, the takeoff rested upon a firm foundation of 'rising agricultural productivity'. The most developed country of Asia, i.e., Japan also owes its present economic position to the development of agriculture sector in the pre-modern industrialization period. (Soni, 2013). Growth in the agricultural sector can help in overall economic growth by releasing labor as well as capital to other sectors in the economy
(Yao, 2000; Gollin et al., 2002 and Humphries and Knowles, 1998). GDP growth originating in agriculture has been more successful in reduction of poverty than rest of the economy (Ravallion and Chen, 2007). Despite the historical role of agriculture in economic development, academic and donor communities have not been taking interest in the sector since mid-1980s. However, now agriculture is back on agenda because increasing agricultural productivity is the surest way to end poverty. It not only helps to increase farm incomes but also stimulates linkages to the non-farm rural economy (Timmer, 2005). On the contrary, the growth process in the manufacturing sector does not significantly impact the agricultural sector (Kanwar, 2000).

Though newspaper headlines prefer to highlight the failure of agriculture like higher food prices, rising hunger, and distress in agriculture etc. but agriculture has many success stories such as accelerating growth, poverty reduction, food security and environmental services and we need to learn from these successes in our development. 
The WDR (2008) emphasized on the use of agriculture as strategic tool for development (De Janvry and Sadoulet, 2009).

South Asia is one of the densely populated areas in the world. It consists of Bangladesh, Bhutan, India, Maldives, Nepal, Pakistan and Sri Lanka. Most of these South Asian economies are based largely on agriculture and historically it has been found that it contributed positively towards overall economic development. Agriculture employs about 60 percent of the labor force in South Asia and contributes 22 percent of the regional gross domestic product (WDR, 2008). Agricultural growth in South Asia is less than 3 percent, which is far below the growth rates of other economic sectors (World Development Report, 2008). Green Revolution of the late sixties and early seventies has brought about a significant transformation in productivity of agricultural sector. However, over the last two decades, due to structural changes that have been taking place in most of the South Asian economies, the share of agriculture in gross domestic product (GDP) has started declining. Since agriculture is one of the key economic sector in South Asian countries therefore priority should be set for improvement of agriculture in the South Asian countries. Economic reforms have been undertaken in most of these countries and now they are looking for a greater role of the industrial sector in the economy.

Structural transformation is essential for economic development. In this process factor of production move across the sector which drive development process (Atiyas, Galal and Selim, 2015). Economic development generally goes parallel with declining share of agriculture in output and employment and leads to structural transformation of economy from agriculture to industrial and services sector (Hnatkovska, and Lahiri, 2013). Gollin et al., (2002) concluded that development of an economy is associated with declining role of agriculture in the economy. Dependence on agriculture may create vicious circle of low productivity and poverty. Industrialization is required to break this circle which by increasing income level leads to higher saving and investment and thereby generates selfsustaining growth (Lewis, 1954; Kaldor, 1967 and Fei and Ranis, 1964). Kuznet (1973) demonstrates that growth of an economy is accompanied with structural changes due to changes in demand and supply with rising income. Demand for agricultural products declines because of low-income elasticity of demand for agricultural product while in contrast demand for industrial goods and services as their elasticity are higher. McMillan and Rodrik (2011) found that structural change has been helpful in productivity growth in Asia but not in Africa and Latin America.

Johnston and Mellor (1961) described five major ways that agriculture can contribute in the economic development i.e (1) Provision of food (2) Raw material to industry (3) Provide domestic market to industrial sector.(4) Foreign exchange earnings (5) Transfer of labour to rest of economic sector. In a review study of agriculture and development, Dethier and Effenberger (2012) explained that agricultural growth has a capacity to overcome poverty in poor and developing countries. Improvement in agricultural productivity is essential to achieve the Sustainable Development Goals. Moreover, Agriculture could be an engine of economic growth and provide employment opportunities for the rural non-farm economy because of its linkages with small cities and rural areas. Non-agricultural sector's growth is backed by resource transfer from agriculture sector (Yao, 2010). Increase in agricultural productivity releases resources for other sectors. For developing countries, the growth in agricultural productivity and sectoral shift in employment is the key to economic growth because effective improvements in agricultural productivity give a big push to the industrialization which largely affects a country's relative income (Gollin et al., 2002; Humphries and Knowles, 1998). Evidence reveal that in all those countries which are rapidly growing at present, agriculture has been the driver for their non-agricultural sectors and overall economic growth. Economic growth through agriculture makes a strong impact in reducing poverty and hunger (Pingali, 2007). De Janvry and Sadoulet (2009) believe that the benefits from a global orientation of the agricultural sector can be pro-poor where the production and post-harvest activities continue to be labour intensive. Winters et al., (1998) argued that industrialization can be successful when solution to the problems associated with the generation, transfer and use of agricultural resources surplus has been identified.

Some other empirical studies have also been done to find the role of agriculture in economic development in different time period and different region. Results of the study by Self and Grabowski (2007) showed that growth of agricultural productivity via agricultural modernization has a positive effect on economic growth and human development. In their empirical study, Tiffin and Irz (2006) Taking data from 85 countries, 
provided evidence that for most of the countries, growth in agricultural value added is a major cause of GDP growth. This view is consistent with the popular paradigm among agricultural economists that agricultural productivity growth is necessary to "get the economy moving" because it releases surplus of food, labor, raw materials, capital, and foreign exchange, while simultaneously generating demand for industrial goods and services. Kanwar (2000) found that agriculture significantly affects income generation in manufacturing and construction sector in India. Ravallion and Datt (1996) analyzed the effects of sectoral pattern of economic growth on poverty in India. They found that poor people always benefitted from rural growth and rural economy and stressed that expansion and growth of primary and tertiary sector should be the central focus of policy for reduction of poverty in India. Awokuse (2009) concluded that agriculture matters for economic growth of African countries. In contrast, some arguments have also been advanced which indicate that industrial development is more necessary for economic development (Szirmai, 2015; Chakravarty and Mitra, 2009; Katuria and Raj, 2009; Cornwall, 1977; Kaldor, 1967).

Review of literature shows that most of economist believe that though relative share of agriculture has declined over time calling for rapid industralization for structural transformation but agriculture still plays an active role in economic development. It is empirically proven that without agricultural development any effort to industrialize an economy may end up in failure. Many empirical studies have been undertaken to analyze the role of agriculture in economic development but results widely vary and often are not comparable. The development economics literature is still inconclusive on how best to promote growth and prosperity in emerging and low-income countries (Cantore et al., 2014). We are undertaking a comprehensive study across the four major countries namely Bangladesh, India, Pakistan and Sri Lanka of South Asia which form together 96.3 percent of South Asia's population in 2016 (WDI, 2017) where a bulk of world population below poverty line lives. Headcount ratio for South Asia was 15.1 in 2015. The specific aims of the study are (1) to ascertain extent of declining of agricultural share in GDP, (2) analyze the compound annual growth of agriculture in these four countries and (3) examine the relationship between agricultural growth and GDP growth using Augmented Neoclassical Solow-Swan model.

\section{Materials and methods}

\section{Conceptual framework and model specification}

To analyze the long-run relationship between agriculture and economic growth, we shall use Augmented Neoclassical Solow-Swan model as suggested by Ruttan (2000), Timmer (1995), Hwa (1988), and used by researchers like Awokuse and Xie (2015), OJO et al. (2014), Samimi and Khyareh (2012) and Awokuse (2009). Our derived empirical function is as follows.

$Y_{t}=K_{t}^{\alpha} A_{t}^{\beta} X_{t}^{\gamma} T_{t}^{\eta}+u_{t}$

After a natural log transformation the equation is

$\ln Y_{t}=\alpha \ln K_{t}+\beta \ln A_{t}+\gamma \ln X_{t}+\eta \ln T_{t}+\varepsilon_{t}$

Where;

$Y=$ Real GDP per capita, (GDP)

$K=$ Real gross capital (GCF)

$A=$ Agricultural value added (AGRI)

$X=$ Real exports (EXP)

$T=$ Terms of Trade (TOT, a proxy for other macroeconomic variable

$\varepsilon=$ Error term (captures other variables that may influence productivity changes not explicitly included in the model)

As discussed in the literature that agriculture is engine of economic growth via support to other sector of the economy (Hwa, 1988). A number of studies have advocated for export-led economic growth. Foreign exchange earnings through export can impact the economy through multiplier effect and can be used to import manufactured and capital goods. It also increases the linkage in industry, and generates positive externalities. This accelerates economic growth. Asian economies provide ample examples of export-led economic growth (AbouStait, 2005; Faridi, 2012). So, we also include additional determinants of growth (exports and terms of trade [TOT]) that have been found to be robust in explaining aggregate productivity growth (Hwa, 1988; and Wunder, 2003). There is enough literature available is support of the argument that Terms of trade has relationships with economic growth (Kalumbu and Sheefeni, 2014; Blattman et al., 2004; and Mendoza, 1997). Wunder (2003) finds evidence that the increase in an economy's TOT could affect other sectors (e.g., the agricultural sector) through the expansion of exports and price booms. Mehta (2011) found empirical 
evidences that show long-run relationship between capital formation and economic growth. Capital formation significantly influences the economic growth (Barro, 1991; Levine and Renalt, 1992; and Beddies, 1999).

\section{Data}

Four South Asian countries are chosen for the study namely India, Pakistan, Bangladesh and Sri Lanka. The study is based on the secondary data. Annual time series data of real GDP, agricultural value added, gross capital formation is use as a proxy for real gross capital, real exports, and TOT have been collected from World Development Indicators provided by the World Bank for India, Pakistan, Bangladesh and Sri Lanka. Data of all variables have been taken in their local currency unit of the countries at constant price. For India data is taken from the period 1980 to 2013, for Pakistan from 1980 to 2014, for Bangladesh 1987 to 2014 and for Sri Lanka 1984 to 2013. Lack of uniformity in time period of study is due to non-availability of data of some variables.

\section{Econometrics approach}

Cointegration tests are most popular approach for analyzing the relationship between different variables. If cointegration is found among variables, it implies a long-run equilibrium relationship among the variables. The same approach has been used in the current study. Unit root test is the precondition of cointegration and causality analysis. Unit root test is performed using an autoregressive model to check whether a time-series variable is nonstationary or not. A series is stationary if the mean and auto covariances of the series do not depend on time. According to Nelson and Plooser (1982), most of the time series that appear in the economy will have to be differenced in order to become stationary. Univariate time-series properties were examined using two unit root tests: Augmented Dickey and Fuller (ADF) test and non-parametric Phillips-Perron (PP) approaches. The test of stationarity were carried out by estimating the following regression equation:

$$
\begin{aligned}
& \Delta \mathrm{Y}_{\mathrm{t}}=\psi \mathrm{Y}_{\mathrm{t}-1}+\sum_{\mathrm{i}=1}^{\mathrm{m}} \beta_{\mathrm{i}} \Delta \mathrm{Y}_{\mathrm{t}-1}+\mu_{\mathrm{t}} \\
& \Delta \mathrm{Y}_{\mathrm{t}}=\beta_{0}+\psi \mathrm{Y}_{\mathrm{t}-1}+\sum_{\mathrm{i}=1}^{\mathrm{m}} \beta_{\mathrm{i}} \Delta \mathrm{Y}_{\mathrm{t}-1}+\mu_{\mathrm{t}} \\
& \Delta \mathrm{Y}_{\mathrm{t}}=\beta_{0}+\psi \mathrm{Y}_{\mathrm{t}-1}+\sum_{\mathrm{i}=1}^{\mathrm{m}} \beta_{\mathrm{i}} \Delta \mathrm{Y}_{\mathrm{t}-1}+\pi \text { Trend }+\mu_{\mathrm{t}}
\end{aligned}
$$

whereas $i$ varies from 1 to $m$

Equation (1) shows the Random walk model without drift and intercept.
Equation (2) shows the random walk model with drift.

Equation (3) shows the random walk with drift and trend.

Here the hypothesis used for inference is following

H0: $\psi=0$ (non stationary series), H1: $\psi \neq 0$ (stationary)

Hence if the test statistic on the $\psi$ is significant will suggest that the $Y_{t}$ series is stationary.

Further, cointegration test has been done to investigate the long-run equilibrium relationship among the variables using Johansen and Juselius (1990) maximum likelihood technique based on VAR model. Johansen's multivariate cointegration modeling technique is widely accepted as an improvement on Engle and Granger (1987) modeling technique. Generalized cointegration equation is given below.

$\Delta Y_{t}=\mu+\sum_{I=1}^{L-1} \Gamma_{I} Y_{t-k}+\Pi Y_{t-1}+\varepsilon_{t}$

Where $Y_{t}$ is an $(n \times 1)$ column vector the variables GDP, AGRI, EXP, GCF, TOT. $\mu$ is an $(n \times 1)$ vector which may include a linear trend term, an intercept term, or both. $\Pi$ denote the coefficient matrices. It contains the information of long run the adjustment to change in $Y_{t} . \Delta$ is operator of first difference, $k$ is indicating lag length determine by the Aikaike's information criterion (AIC) it is best criteria to chose lag length for small sample (Liew, 2004). $\varepsilon_{t}$ is the error term. Intercept with linear deterministic trends is allowed to analyze the cointegrating equation (4). Johansen proposes two methods for determining the cointegration rank, the $\lambda \max$ test and the trace test.

Finally, Granger causality test has been employed to analyze causal relations between agriculture and economic growth in short run. This test predicts how much of the current value of GDP is explained by past value of agricultural value added vice-versa. GDP is said to be Granger-caused by Agricultural value added if agricultural value added helps in the prediction of GDP or equivalently if the coefficient on the lagged Agricultural value added is statistically significant. Specifically, AGRI is causing $G D P_{t}$ if some coefficient, $\Phi_{i}$, is non-zero in the following equation.

$$
G D P_{t}=\alpha_{0}+\sum_{i=1}^{k} \Phi_{i} \operatorname{AGRI}_{t-1}+\sum_{j=1}^{k} \Psi_{j} G D P_{t-j}+\varepsilon_{t}
$$


Similarly $G D P_{t}$ is causing $A G R I$, if some coefficient, $\Theta_{i}$, is non-zero in the following equation.

$A G R I_{t}=\beta_{0}+\sum_{i=1}^{k} \theta_{i} G D P_{t-1}+\sum_{j=1}^{k} \delta_{j} A G R I_{t-j}+\mu_{t}$

Some diagnostic and stability test such as Jerca Bera test for normality, Breusch-Godfrey for serial correlation, Breusch-Pagan-Godfrey for Heteroskedasticity, CUSUM test and CUSUM of square test are examined for model satisfactoriness.

\section{Results and discussion}

\section{Structural transformation in South Asian countries}

Structural transformation refers to the change in the composition of sectoral output in the economy over a period of time. Structural transformation of South Asian economies is presented in the table 1 .

Table 1 shows that in 1960, agriculture contributed 57.5 percent in the economy of Bangladesh while the contribution of non-agriculture sector was 42.5 percent. But in 1990, share of agriculture sector declined to 32.7 percent and a sharp increase in industrial sector has been observed from 6.9 percent in 1960 to 20.7 percent in 1990 . In 2014, agriculture share further declined to 15.8 percent, while that of industrial and service sector increased to 27.8 and 56.2 percent respectively. In India also a drastic change in the sectoral composition is found. In 1960, agricultural contributed 42.5 percent in the economy which declined to 29.0 percent in 1990, while the contribution of services sector increased to 44.4 percent from 38.14 percent and industrial sectors went up to 26.5 percent from 19.3 percent over the same period. Similar trend has been observed from 1990 onwards, when share of agricultural sector came down to 16.9 percent in 2014 and services sector reached to 52.9 percent. A noticeable trend in case of India is that the contribution of industrial sector has shown only marginal improvement from 26.4 percent to 30.0 percent during 1990 to 2014 . This implies that in post-liberalization era industrial sector could not grow at the pace expected. Major cause for this has been increased inflow of foreign industrial goods from abroad especially from China due to reduction in tariffs as well as non-tariff barriers by government of India. It is the fast expansion of services sector which has caused declined in the share of agriculture. Similarly, between the periods of 1960-1990, in the economy of Pakistan, agriculture share has declined from 46.2 percent to 25.9 percent, while the contribution of industrial sector increased to 25.1 percent from 15.6 percent and services sector increased from 38.1 percent to 48.8 percent. But 1990 onwards, share of agriculture has remained stagnant at near about 25 percent and industrial sector declined to 21.2 percent and services sector increased to 53.6 percent in 2014. This clearly reflects that Pakistan economy suffered structural retrogression after 1990. Lack of infrastructure facilities and weak government policies have been major stumbling blocks in industrial expansion in Pakistan. While private domestic investment grew slowly, foreign investment shied away because of political uncertainties and growth of fundamentalist tendencies. As far as Sri Lanka is concerned, agriculture sector has marginally declined from 31.6 percent in 1960 to 26.3 percent

\begin{tabular}{|c|c|c|c|c|c|c|}
\hline & Agriculture & Industry & Services & Agriculture & Industry & Services \\
\hline Bangladesh & & & & & & \\
\hline 1960 & 57.47 & 6.97 & 35.55 & 42.56 & 19.30 & 38.14 \\
\hline 1990 & 32.75 & 20.70 & 46.55 & 29.02 & 26.49 & 44.48 \\
\hline 2010 & 17.81 & 26.14 & 56.05 & 18.21 & 27.16 & 54.64 \\
\hline 2014 & 15.89 & 27.87 & 56.24 & 16.96 & 30.05 & 52.99 \\
\hline Pakistan & & & & & & \\
\hline 1960 & 46.22 & 15.60 & 38.18 & 31.66 & 20.40 & 47.95 \\
\hline 1990 & 25.98 & 25.19 & 48.83 & 26.32 & 25.97 & 47.71 \\
\hline 2010 & 24.29 & 20.58 & 55.13 & 12.81 & 29.43 & 57.76 \\
\hline 2014 & 25.12 & 21.28 & 53.59 & 9.86 & 33.81 & 56.33 \\
\hline
\end{tabular}

Source: WDI data (2015) 
in 1990 and a similar marginal improvement has been observed in industrial sector from 20.4 percent to 25.9 percent, but services sector remained stagnant. After 1990, agriculture sector has declined sharply to 9.8 percent in 2014 while both industrial and service sector increased considerably.

From the above trend following conclusions about structural transformation in South Asian Countries emerge:

(1) In all economies, relative importance of agriculture sector has declined though the degree of decline has varied from country to country. Bangladesh recorded sharper decline in agriculture followed by India and Sri Lanka, in case of Pakistan process of decline has been very slow.

(2) Bangladesh has succeeded in industrializing its economy at a relatively faster pace, recording more than four-fold increase in its share. While India and Sri Lanka achieved modest industrial expansion, Pakistan has lagged behind considerably in industrial expansion.

(3) Services sector have been major sources of economic growth and structural transformation in India, Bangladesh, and Pakistan, but its role was limited in Sri Lanka as it already had a very large share.

Performance of agricultural value added and GDP in South Asian Countries

Table 2 reveals the results of correlation coefficient and decade-wise CAGR of agriculture and economic growth of major South Asian countries. Correlation between growth in agricultural value added and GDP has been strongly positive for Bangladesh and India while moderate in case of Pakistan and Sri Lanka. Decade-wise average growth shows high degree of fluctuation in agricultural growth of Bangladesh followed by Pakistan, India and Sri Lanka while in case of overall GDP growth almost similar variations are observed. This clearly demonstrate that growth in agricultural value added is crucial for sustainable economic growth in South Asian countries. Now we shall analyse the relationship between agricultural value-added and economic growth more closely by using econometric techniques.

\section{Cointegration and long run estimates}

We have found correlation between agriculture value added and agricultural growth across South Asian countries, though degree of correlation is lower in case of Pakistan and Sri Lanka. Now we shall examine the relationship between agriculture value added and GDP more closely by applying cointegration approach.

First of all we check stationarity of the series by using $\mathrm{ADF}$ and $\mathrm{PP}$ tests. $\mathrm{ADF}$ and $\mathrm{PP}$ determine the unit root test using parametric and non-parametric approaches respectively. Both tests are examined for null hypothesis of non-stationarity. Results of tests are given in the table 3. At level, time series of all four countries has unit root. However, at first difference all series are stationary. It provides sufficient condition to test Johansen and Juselius (1990) multivariate cointegration test which has been done in table 4 . This test has been done to analyze whether the long run relationship exists or not.

Table 4 reveals that Trace statistics $\left(\lambda_{\text {trace }}\right)$ rejects the null hypothesis $(\mathrm{r}=0)$ for all four countries vis Sri Lanka, Pakistan, India and Bangladesh at 5 percent significant level. Row 2 of table 4 shows that the null hypothesis of Cointegration rank, $(r \leq 1)$, is not rejected for all countries. Similarly max-eigenvalue $\left(\lambda_{\text {max }}\right)$ reject thenullhypothesis $(r \leq 1)$ at 5 percent level of significance for Bangladesh, Pakistan and Sri Lanka but for India test value is slightly more than critical value at $5 \%$

\begin{tabular}{|c|c|c|c|c|c|c|c|c|}
\hline \multirow[b]{2}{*}{ year } & \multicolumn{2}{|c|}{ Bangladesh } & \multicolumn{2}{|c|}{ India } & \multicolumn{2}{|c|}{ Pakistan } & \multicolumn{2}{|c|}{ Sri Lanka } \\
\hline & Agriculture & GDP & Agriculture & GDP & Agriculture & GDP & Agriculture & GDP \\
\hline $1960-70$ & 2.7 & 3.6 & 2.0 & 3.6 & 4.8 & 6.9 & 2.9 & 4.5 \\
\hline $1970-80$ & 0.5 & 1.7 & 1.8 & 3.3 & 2.3 & 4.6 & 2.7 & 4.5 \\
\hline $1980-90$ & 2.0 & 3.7 & 3.1 & 5.3 & 4.0 & 6.1 & 2.1 & 3.9 \\
\hline $1990-00$ & 2.6 & 4.6 & 3.1 & 5.8 & 4.3 & 3.7 & 1.9 & 5.1 \\
\hline $2000-10$ & 4.3 & 5.6 & 3.1 & 7.5 & 3.3 & 4.7 & 3.1 & 5.5 \\
\hline 2010-14 & 3.2 & 6.1 & 2.6 & 6.2 & 2.7 & 3.9 & 3.2 & 7.0 \\
\hline $\mathrm{r}$ & +0.89 & & +0.85 & & +0.54 & & +0.55 & \\
\hline
\end{tabular}

Note: $r$ denotes correlation coefficient

Source: WDI data (2015)

Table 2: Decade-wise Compound Annual Growth Rate (CAGR) of agricultural value added and GDP. 
and null hypotheses is rejected at 10 percent $(\mathrm{P}$-value $=0.0 .057)$ level of significance. From the results it can be concluded that there is a cointegration among the variables and there exists long-run relationship between agriculture and economic growth.

\begin{tabular}{|c|c|c|c|c|}
\hline \multirow[b]{2}{*}{ At level } & \multicolumn{2}{|c|}{ Sri Lanka } & \multicolumn{2}{|c|}{ Pak } \\
\hline & ADF & PP & ADF & $\mathbf{P P}$ \\
\hline AGRI & $0.40(0.980)$ & $0.58(0.987)$ & $-2.29(0.425)$ & $-2.20(0.475)$ \\
\hline EXP & $-1.54(0.794)$ & $-1.41(0.839)$ & $-2.01(0.575)$ & $-2.08(0.536)$ \\
\hline GCF & $1.55(0.999)$ & $3.80(1.000)$ & $-2.82(0.066)$ & $-2.82(0.066)$ \\
\hline GDP & $-0.04(0.993)$ & $-0.20(0.990)$ & $-2.35(0.398)$ & $-2.47(0.341)$ \\
\hline TOT & $-0.52(0.484)$ & $-0.61(0.444)$ & $-1.59(0.103)$ & $-1.66(0.090)$ \\
\hline \multicolumn{5}{|c|}{ At $1^{\text {st }}$ difference } \\
\hline AGRI & $-6.27(0.000)$ & $-6.27(0.000)$ & $-7.27(0.000)$ & $-13.97(0.000)$ \\
\hline EXP & $-5.11(0.001)$ & $-6.25(0.000)$ & $-6.37(0.000)$ & $-6.38(0.000)$ \\
\hline GCF & $-5.37(0.000)$ & $-5.40(0.000)$ & $-4.81(0.000)$ & $-4.80(0.000)$ \\
\hline GDP & $-4.84(0.002)$ & $-4.84(0.002)$ & $-3.64(0.041)$ & $-3.60(0.045)$ \\
\hline \multirow[t]{2}{*}{ TOT } & $-5.40(0.000)$ & $-5.41(0.000)$ & $-5.55(0.000)$ & $-5.56(0.000)$ \\
\hline & \multicolumn{3}{|c|}{ India } & Bangladesh \\
\hline At level & ADF & $\mathbf{P P}$ & ADF & $\mathbf{P P}$ \\
\hline AGRI & $0.018(0.953)$ & $0.17(0.966)$ & $-1.77(0.689)$ & $-2.17(0.486)$ \\
\hline EXP & $-2.98(0.1644)$ & $-3.43(0.064)$ & $-2.58(0.296)$ & $-2.12(0.514)$ \\
\hline GCF & $-1.81(0.676)$ & $-1.82(0.673)$ & $1.77(0.999)$ & $1.45(0.999)$ \\
\hline GDP & $-1.01(0.929$ & $-0.79(0.957)$ & $-0.78(0.955)$ & $-1.55(0.787)$ \\
\hline TOT & $1.03(0.917)$ & $2.57(0.997)$ & $0.17(0.966)$ & $0.58(0.987)$ \\
\hline \multicolumn{5}{|c|}{ At $1^{\text {st }}$ difference } \\
\hline AGRI & $-9.62(0.000)$ & $-22.13(0.000)$ & $-4.01(0.024)$ & $-4.54(0.007)$ \\
\hline EXP & $-5.25(0.001)$ & $-5.23(0.001)$ & $-4.22(0.013)$ & $-4.11(0.014)$ \\
\hline GCF & $-5.74(0.000)$ & $-5.74(0.000)$ & $-3.98(0.005)$ & $-3.99(0.005)$ \\
\hline GDP & $-5.54(0.000)$ & $-6.87(0.000)$ & $-4.71(0.004)$ & $-4.71(0.004)$ \\
\hline TOT & $-6.37(0.000)$ & $-6.39(0.000)$ & $-6.71(0.000)$ & $-6.84(0.000)$ \\
\hline
\end{tabular}

Note: Trend and intercept are included for AGRI, GCF, GDP and Intercept for TOT while for export Trend and intercept for Sri Lanka and for rest of the countries Intercept included in ADF and PP Test Source: WDI data (2015)

Table 3: ADF and PP Test.

\begin{tabular}{lcccc}
\hline & Sri Lanka & Pakistan & India & Bangladesh \\
\hline Cointegration rank & & Value of Trace statistics & & \\
\hline $\mathrm{r}=0$ & $99.097^{*}$ & $101.58^{*}$ & $81.023^{*}$ & $99.259^{*}$ \\
& $(0.007)$ & $(0.004)$ & $(0.005)$ & $(0.007)$ \\
$\mathrm{r} \leq 1$ & 59.961 & 60.05 & 47.656 & 52.738 \\
& $(0.102)$ & $(0.101)$ & $(0.052)$ & $(0.301)$ \\
$\mathrm{r} \leq 2$ & 35.177 & 35.145 & 26.147 & 33.971 \\
& $(0.238)$ & $(0.239)$ & $(0.124)$ & $(0.326)$ \\
$\mathrm{r} \leq 3$ & 16.583 & 18.031 & 12.983 & 16.212 \\
& $(0.447)$ & $(0.342)$ & $(0.115)$ & $(0.474)$ \\
$\mathrm{r} \leq 4$ & 6.201 & 6.007 & 3.686 & 4.152 \\
& $(0.435)$ & $(0.459)$ & $(0.155)$ & $(0.720)$ \\
\hline
\end{tabular}

Note: * denote $5 \%$ level of significance, $* *$ denote $10 \%$ levels of significance, P-value are given in parenthesis Source: WDI data (2015) 


\begin{tabular}{lcccc}
\hline & Sri Lanka & Pakistan & India & Bangladesh \\
\hline Cointegration rank & & Value of $\lambda$-max statistics & & $46.521^{*}$ \\
\hline $\mathrm{r}=0$ & $39.136^{*}$ & $41.527^{*}$ & $33.367 * *$ & $(0.005)$ \\
& $(0.040)$ & $(0.021)$ & $(0.057)$ & 19.525 \\
$\mathrm{r} \leq 1$ & 24.784 & 24.905 & 21.509 & $(0.689)$ \\
$\mathrm{r} \leq 2$ & $(0.299)$ & $(0.292)$ & $(0.247)$ & 16.978 \\
$\mathrm{r} \leq 3$ & 18.594 & 17.113 & 13.164 & $(0.459)$ \\
$\mathrm{r} \leq 4$ & $(0.333)$ & $(0.448)$ & $(0.437)$ & 12.081 \\
& 10.382 & 12.024 & 9.297 & $(0.408)$ \\
& $(0.578)$ & $(0.413)$ & $(0.262)$ & 4.152 \\
\end{tabular}

Note: * denote $5 \%$ level of significance, ${ }^{* *}$ denote $10 \%$ levels of significance, $\mathrm{P}$-value are given in parenthesis Source: WDI data (2015)

Table 4: Johansen's cointegration test results (continuation).

\begin{tabular}{lcccccc}
\hline \multicolumn{7}{c}{ Coefficient and T-value of long-run regression } \\
\hline Countries & Constant & AGRI & EX & GCF & TOT & R-square \\
\hline \multirow{2}{*}{ Bangladesh } & 8.726 & 1.394 & 0.31 & 0.038 & -0.065 & 0.35 \\
& & {$[-17.127]$} & {$[-14.344]$} & {$[1.058]$} & {$[1.667]$} & \\
\multirow{2}{*}{ India } & 0.229 & 0.482 & 0.063 & 0.494 & 0.012 & 0.49 \\
& & {$[-4.734]$} & {$[-1.383]$} & {$[-8.706]$} & {$[0.030]$} & \\
Pakistan & 12.932 & 0.311 & 0.12 & 1.07 & 0.082 & 0.57 \\
& & {$[-1.093]$} & {$[-0.581]$} & {$[-2.683]$} & {$[-0.678]$} & \\
\multirow{2}{*}{ Sri Lanka } & \multirow{2}{*}{0.917} & 0.969 & 0.377 & 0.099 & -0.247 & 0.51 \\
& & {$[-9.326]$} & {$[-13.349]$} & {$[-2.181]$} & {$[5.633]$} & \\
\hline
\end{tabular}

Note: T-value are given in parenthesis

Source: WDI data (2015)

Table 5: Results of long-run regression.

Table 5 indicates the Long-run estimates. Out of all four regressors our main interest is to discuss the impact of agriculture on economic growth. Results shows that agriculture makes a positive and significant impact on economic growth is south Asian countries. The effect of agriculture on economic growth is stronger for Bangladesh, India and Sri Lanka while for Pakistan though positive but not significant at $5 \%$ percent level. This result supports the hypotheses of early development economists that agriculture is an engine of economic growth. In spite of structural transformation in economies of all four countries, policy initiatives have continuously been undertaken to improve agriculture sector in all four South Asian countries. Progress of rural electrification and the financial transformations in the mid-nineties led to the increased commercialized agriculture in Bangladesh. In India policy initiatives such as high yielding variety of seeds (HYVS), research and extension services of agriculture, the supply of inputs such as chemical fertilizers and pesticides, emphasis on the provision of agricultural credit and crop insurance has transformed agriculture from subsistence to semicommercialized and commercialized one (Arora, 2013, Mandal and Bezbaruah, 2013; Kumar, et al.,2012). Sri Lankan government consistently emphasized on the development of agriculture through several policy packages such as land reforms and Social development programs taking agriculture as a central theme. Pakistan does not have a formal operative "Agriculture Policy" at present, instead ad-hoc policy measures are framed from time to time to strengthen agriculture (Khan, 2015).

An export is crucial for economic activity to generate foreign exchange and stimulate growth. Table 6 indicates the role of export in economy. Analysis reveal that export has strong and positive impact on economic growth for Bangladesh, India, and Sri Lanka while for Pakistan export though 


\begin{tabular}{|c|c|c|c|c|}
\hline & \multicolumn{2}{|c|}{ Bangladesh } & \multicolumn{2}{|c|}{ India } \\
\hline & F-Statistic & P-value & F-Statistic & P-value \\
\hline AGRI does not Granger Cause GDP & 1.535 & 0.240 & $5.16^{*}$ & 0.031 \\
\hline \multirow[t]{3}{*}{ GDP does not Granger Cause AGRI } & 4.445 & 0.025 & $3.21 * * *$ & 0.085 \\
\hline & \multicolumn{2}{|c|}{ Pakistan } & \multicolumn{2}{|c|}{ Sri Lanka } \\
\hline & F-Statistic & P-value & F-Statistic & P-value \\
\hline AGRI does not Granger Cause GDP & $4.109 * *$ & 0.032 & $5.747 * *$ & 0.024 \\
\hline GDP does not Granger Cause AGRI & 1.187 & 0.325 & $18.637 *$ & 0.000 \\
\hline
\end{tabular}

Note: * Significant at $1 \%, * *$ Significant at $5 \%, * * *$ Significant at $10 \%$

Source: WDI data (2015)

Table 6: Short-run estimates.

has a positive but weak impact on the growth of economy. For all four countries Coefficient of gross capital formation was found positive and highly significant which is consistent with neoclassical growth theory. South Asian economies are increasing capital formation to obtain higher economic growth. Variations in term of trade also affect economic growth of a country (Kalumbu and Sheefeni, 2014; Blattman et al., 2004; Wunder, 2003 and Mendoza, 1997). For India and Pakistan terms of trade has been positive while for Bangladesh and Sri Lanka it has been negative.

Granger causality analysis has been employed to estimates the hypothesis ALG (agriculturalled growth) and GLA (growth led agriculture) in the short- run for all four countries based on the ECM. The null hypotheses are agriculture does not Granger-cause GDP and GDP growth does not Granger-cause agricultural. Results are shown in the table 6. Mixed results are found on the contribution of agriculture to economic growth in the short-run. For India, we found bidirectional causality, both ALG and GLA is statistically significant. Agriculture is granger cause of GDP and the reverse GDP is granger cause of agriculture, but former is significant at 5 percent while later is significant at 10 percent level. In Pakistan unidirectional causality is found, agriculture stimulates GDP growth while reverse is not found significant. For Sri Lanka strong bidirectional causality is found. Null hypotheses that agriculture does not granger cause GDP is rejected at 5 percent while GDP does not granger cause agriculture is rejected at 1 per cent.
For Bangladesh causality has been running from GDP to agriculture. Agricultural growth is led by the overall GDP growth. These results confirm finding of similar previous studies for developing countries (Awokuse and Xie, 2015; Tiffin and Irz, 2006 ).

\section{Conclusion}

In the present study empirical analysis has been undertaken to examine the role of agriculture in economic growth for South Asian economies. Due to unavailability of data only four South Asian countries namely India, Pakistan, Bangladesh and Sri Lanka have been chosen for study. South Asian countries have witnessed structural transformation over time resulting in the declining share of agriculture. But agriculture sector still is crucial for their economic growth and development. Fluctuation in agriculture still leads to fluctuation in overall GDP growth in South Asian countries. Our results show that in all four South Asian countries, agriculture has long-run association with economic growth and it is an important driver of economic growth. Short-run analysis indicates that agriculture stimulates growth in all South Asian countries except Bangladesh. In addition, bidirectional relationship between agriculture and economic growth is found for India and Sri Lanka. National policymakers of these countries should recognize the role of agriculture in economic planning and formulate their economic development strategies accordingly. Neglect of agriculture and excessive focus on industrialization may retard growth both in short and long run.

\section{Corresponding authors:}




\section{References}

[1] Abou-Stait, F. (2005) "Are Exports the Engine of Economic Growth? An Application of Cointegration and Causality Analysis for Egypt, 1977 - 2003", Economic Research Working Paper no. 76 July, Tunis: African Development Bank. [Online]. Available: http://www.afdb.org [Accessed: 15 Feb. 2018].

[2] Kumar, A., Kumar, P. and Sharma, A. N. (2012) "Crop diversification in Eastern India: Status and determinants“, Indian Journal of Agricultural Economics, Vol. 67, No. 4, pp. 600-616. ISSN 0019-5014.

[3] Arora, V. P. S. (2013) "Agricultural policies in India: Retrospect and prospect", Agricultural Economics Research Review, Vol. 26, No. 2, pp.135-157. ISSN 0971-3441.

[4] Awokuse, T. O. (2009) "Does agriculture really matter for economic growth in developing countries?", In Annual Meeting, July 26-28, 2009, Milwaukee, Wisconsin (No. 49762), Agricultural and Applied Economics Association.

[5] Awokuse, T. O. and Xie, R. (2015) "Does agriculture really matter for economic growth in developing countries?" Canadian Journal of Agricultural Economics, Vol.63, No.1, pp.77-99. ISSN 0008-3976. DOI 10.1111/cjag.12038.

[6] Barro, R. J. (1991) "Economic growth in a cross section of countries", The quarterly journal of economics, Vol.106, No.2, pp. 407-443. ISSN 1531-4650. DOI 10.2307/2937943.

[7] Beddies, M. C. H. (1999) "Investment, Capital Accumulation, and Growth: Some Evidence From the Gambia 1964-1998" , No. 99-117, International Monetary Fund.

[8] Blattman, C., Hwang, J. and Williamson, J. G. (2004) "The impact of the terms of trade on economic development in the periphery 1870-1939: Volatility and secular change", No. w10600. National Bureau of Economic Research.

[9] Cantore, N., Clara, M. and Saore, C. (2014) "Manufacturing as an engine of growth: Which is the best fuel?", Working Paper No. 01/2014. Vienna, Austria: UNIDO.

[10] Chakravarty, S. and Mitra, A. (2009) "Is industry still the engine of growth? An econometric study of the organized sector employment in India", Journal of Policy Modeling, Vol. 31, No.1, pp.22-35. ISSN 0161-8938. DOI 10.1016/j.jpolmod.2008.06.002.

[11] Cornwall, J. (1977) “Modern capitalism: its growth and transformation”, London: Martin Robertson, 226 p. ISBN 0855201525.

[12] De Janvry, A. and Sadoulet, E. (2009) "Agriculture for development: Lessons from the World Development Report 2008“, QA Rivista dell'Associazione Rossi-Doria, Vol. 1, pp. 9-24.

[13] Dickey, D. A. and Fuller, W. A. (1979) "Distribution of the estimators for autoregressive time series with a unit root", Journal of the American Statistical Association, Vol.74, No. 366a, pp. 427-431. ISSN 1537-274X. DOI 10.2307/2286348.

[14] Dethier, J. J. and Effenberger, A. (2012) "Agriculture and development: A brief review of the literature", Economic Systems, Vol. 36, No. 2, pp. 175-205. ISSN 0939-3625. DOI 10.1016/j.ecosys.2011.09.003.

[15] Engle, R. F. and Granger, C. W. (1987) "Co-integration and error correction: representation, estimation, and testing", Econometrica, Vol.55, No. 2, pp. 251-276. ISSN 1468-0262. DOI 10.2307/1913236.

[16] Faridi, M. Z. (2012) "Contribution of Agricultural Exports to Economic Growth in Pakistan", Pakistan Journal of Commerce and Social Sciences, Vol. 6, No. 1, pp. 133-146. ISSN 2309-8619.

[17] Fei, J. C. H. and Ranis, G. (1964) "Development of the Labor Surplus Economy. Theory and Policy", Homewood, Ill., Irwin.

[18] Gollin, D., Parente, S. and Rogerson, R. (2002) "The role of agriculture in development", The American Economic Review, Vol. 92, No. 2, pp.160-164. ISSN 0002-8282. DOI 10.1257/000282802320189177. 
[19] Hnatkovska, V. and Lahiri, A. (2013) "Structural transformation and the rural-urban divide" University of British Columbia, typescript. [Online]. Available: https://www.isid.ac.in/ pu/ conference/dec_12_conf/Papers/AmartyaLahiri.pdf [Accessed: 20 Jan. 2018].

[20] Humphries, H. and Knowles, S. (1998) "Does agriculture contribute to economic growth? Some empirical evidence", Applied Economics, Vol. 30, No. 6. pp. 775-781. ISSN 0003-6846. DOI 10.1080/000368498325471.

[21] Hwa, E. C. (1988) "The contribution of agriculture to economic growth: some empirical evidence", World Development, Vol. 16, No. 11, pp. 1329-1339. ISSN 0305750X. DOI 10.1016/0305-750X(88)90208-2.

[22] Izak, A., Galal, A. and Selim, H. (2015) "Structural Transformation and Industrial Policy: Volume 1: A Comparative Analysis of Egypt, Morocco, Tunisia and Turkey", Luxembourg: European Investment Bank.

[23] Johnston, B. F. and Mellor, J. W. (1961) "The role of agriculture in economic development", The American Economic Review, Vol. 51, No. 4, pp.566-593. ISSN 0002-8282.

[24] Johansen, S. and Juselius, K. (1990) "Maximum likelihood estimation and inference on cointegration - with applications to the demand for money", Oxford Bulletin of Economics and statistics, Vol. 52, No. 2, pp.169-210. ISSN 0305-9049. DOI 10.1111/j.1468-0084.1990.mp52002003.x.

[25] Kanwar, S. (2000) "Does the dog wag the tail or the tail the dog? Cointegration of Indian agriculture with nonagriculture", Journal of Policy Modeling, Vol. 22, No. 5, pp. 533-556. ISSN 0161-8938. DOI 10.1016/S0161-8938(97)00161-0.

[26] Kalumbu, S. A. and Sheefeni, J. P. S. (2014) "Terms of trade and economic growth in Namibia", International Review of Research in Emerging Markets and the Global Economy, Vol.1, No. 3, pp. 90-101. ISSN 2311-3200.

[27] Kaldor, N. (1967) "Strategic Factors in Economic Development", New York State School of Industrial and Labor relations, Cornell University, Ithaca, NY, USA.

[28] Kathuria, V. and Raj, R. S. N. (2009) "Is manufacturing an engine of growth in India? Analysis in the post nineties", In Paper for the UNU-WIDER/UNU-MERIT/UNIDO Workshop, Pathways to Industrialisation in the $21^{\text {st }}$ Century. New Challenges and Emerging Paradigms, Maastricht (2223).

[29] Khan, M. A. (2015) "Promotion of Agriculture in Pakistan. Background paper", Pakistan Institute of Development and Transparency. Islamabad, Pakistan. [Online]. Available: http://www.millat. com/wp-content/uploads/pdf/democracy/PromotionofAgriculturalinPakistan_BackgroundPaper.pdf [Accessed: 25 Jan. 2018]. ISBN 978-969-558-546-7.

[30] Kuznets, S. (1973) "Modern economic growth: findings and reflections", The American economic review, Vol. 63, No. 3, pp. 247-258. ISSN 0002-8282.

[31] Lewis, W. A. (1954) "Economic development with unlimited supplies of labour", The Manchester School, Vol. 22, No. 2, pp.139-191. DOI 10.1111/j.1467-9957.1954.tb00021.x.

[32] Liew, K.S. (2004) "Which lag length selection criteria should we employ?", Economics Bulletin, Vol.3, No.33, pp.1- 9. ISSN: 0957-1337.

[33] Levine, R. and Renelt, D. (1992) "A sensitivity analysis of cross-country growth regressions", The American Economic Review, Vol. 82, No. 4, pp. 942-963. ISSN 0002-8282.

[34] Mandal, R. and Bezbaruah, M. P. (2013) "Diversification of cropping pattern: Its determinants and role in flood affected agriculture of Assam Plain", Indian Journal of Agricultural Economics, Vol. 68, No. 2, pp. 170-181. ISSN 0019-5014.

[35] McMillan, M. S. and Rodrik, D. (2011) "Globalization, structural change and productivity growth", No. w17143, National Bureau of Economic Research.

[36] Mehta, R. (2011) "Short-run and long-run relationship between capital formation and economic growth in India", Indian Journal of Management and Technology, Vol.19, No. 2, pp. 170-180. 
[37] Mendoza, E. G. (1997) "Terms-of-trade uncertainty and economic growth", Journal of Development Economics, Vol. 54, No. 2, pp. 323-356. ISSN 0304-3878. DOI 10.1016/S0304-3878(97)00046-1.

[38] Nelson, C. R. and Plosser, C. R. (1982) "Trends and random walks in macroeconomic time series: some evidence and implications", Journal of Monetary Economics, Vol. 10, No. 2, pp. 139-162. ISSN 0304-3932. DOI 10.1016/0304-3932(82)90012-5.

[39] Ojo, E. J., Awe, I. T. and Ogunjobi, J. O. (2014) "Agricultural export and economic growth in Nigeria: A multivariate Johansen cointegration analysis", International Journal of Arts and Commerce, Vol. 3, No. 3, pp. 89-98. ISSN 1929-7106.

[40] Pingali, P. (2007) "Agricultural growth and economic development: a view through the globalization lens", Agricultural Economics, Vol. 37, No. s1, pp. 1-12. ISSN 1574-0862. DOI 10.1111/j.1574-0862.2007.00231.x.

[41] Ravallion, M. and Datt, G. (1996) "How important to India's poor is the sectoral composition of economic growth?", The World Bank Economic Review, Vol. 10, No. 1, pp. 1-25. ISSN 1564-698X. DOI 10.1093/wber/10.1.1.

[42] Ravallion, M. and Chen, S. (2007) "China's (uneven) progress against poverty", Journal of Development Economics, Vol. 82, No. 1, pp. 1-42. ISSN 0304-3878. DOI 10.1016/j.jdeveco.2005.07.003.

[43] Rostow, W. W. (1959) "The stages of economic growth", The Economic History Review, Vol. 12, No. 1, pp. 1-16. ISSN 1468-0289. DOI 10.1111/j.1468-0289.1959.tb01829.x.

[44] Ruttan, V. W. (2000) "Technology, growth, and development: an induced innovation perspective", OUP Catalogue.

[45] Samimi, A. J. and Khyareh, M. M. (2012) "Agriculture and Economic Growth: The Case of Iran", International Journal of Economics and Management Engineering, Vol. 2, No. 4, pp. 160-166. ISSN 2225-742X.

[46] Self, S. and Grabowski, R. (2007) "Economic development and the role of agricultural technology", Agricultural Economics, Vol. 36, No. 3, pp. 395-404. ISSN 1574-0862. DOI 10.1111/j.1574-0862.2007.00215.x.

[47] Soni, R. N. (2013) "Leading Issues In Agricultural Economics", Vishal Publication Co. ISBN-9788188646807.

[48] Szirmai, A. (2015) "Industrialisation as an engine of growth in developing countries, 1950-2005", Structural Change and Economic Dynamics, Vol. 23, No. 4, pp. 406-420. ISSN 0954-349X. DOI 10.1016/j.strueco.2011.01.005.

[49] Tiffin, R. and Irz, X. (2006) "Is agriculture the engine of growth?", Agricultural Economics, Vol. 35, No.1, pp. 79-89. ISSN 1574-0862. DOI 10.1111/j.1574-0862.2006.00141.x.

[50] Timmer, C.P . (1995) "Getting agriculture moving: do markets provide the right signals?", Food Policy, Vol. 20, No. 5, pp. 455-472. ISSN 0306-9192. DOI 10.1016/0306-9192(95)00038-G.

[51] Timmer, P. (2005) "Agriculture and pro-poor growth: What the literature says", Draft paper, Agricultural and Rural Development Dept., World Bank, Washington, DC.

[52] Winters, P., De Janvry, A., Sadoulet, E. and Stamoulis, K. (1998) "The role of agriculture in economic development: visible and invisible surplus transfers", The Journal of Development Studies, Vol. 34, No.5, pp. 71-97. ISSN 0022-0388. DOI 10.1080/00220389808422537.

[53] World Development Report (2008) "Agriculture for Development", World Bank/Oxford University Press, Washington, DC/Oxford.

[54] Wunder, S. (2003) "Oil wealth and the fate of the forest: a comparative study of eight tropical countries", Routledge. London, UK. 432 p. ISBN-10: 0415278678

[55] Yao, S. (2000) "How important is agriculture in China's economic growth?", Oxford Development Studies, Vol. 28, No.1, pp. 33-49. ISSN 1360-0818. DOI 10.1080/713688306. 